\title{
Floral diversity and ecology in Kalyani area of Nadia district, West Bengal, India
}

\author{
Saikat Biswas, Mayum Maiti, Gita Bhandari, Rimpa Batabyal, Jhilam Patra, Anirban Bhuiya, Bratati \\ Ojha, Nilu Halder and Dibyendu Talukdar ${ }^{\otimes}$
}

\begin{abstract}
An assessment of plant diversity was carried out to record different species of flowering plants (Angiosperms) in Kalyani township of Nadia district, West Bengal, India during January, 2014. All together 6 quadrats were laid down, and 30 flowering plant species belonging to 15 families were documented. Voucher specimens were preserved and digitized in departmental phyto-informatics center. Frequency and density varied greatly among the taxa, while many species were not evenly abundant in the study area. Out of total species, 11 species can be used as economic and medicinal plants. There are also some alien invasive species of diverse origin.
\end{abstract}

Keywords: diversity; quadrat; biological invasions; medicinal plants

\section{Introduction}

The state of West Bengal is located between $85^{\circ} 50^{\prime}$ and $89^{\circ} 50^{\prime} \mathrm{E}$ and $21^{\circ} 38^{\prime}$ and $27^{\circ} 10^{\prime} \mathrm{N}$, and one of the biodiversity rich states in India (Talukdar and Talukdar, 2012; Talukdar, 2013a). The lower Indo-Gangetic basin constitutes fertile hub for diverse

Received: 15 October 2014

Accepted revised version: 22 December 2014

Published online: 08 February 2015

(C) Biswas et al. (2015)

Publisher: Horizon e-Publishing Group

CITATION

Biswas, S., M. Maiti, G. Bhandari, R. Batabyal, J. Patra, A. Bhuiya, B. Ojha, N. Halder, and D. Talukdar. 2015. Floral diversity and ecology in Kalyani area of Nadia district, West Bengal, India. Plant Science Today 2(1): 38-42. doi: 10.14719/pst.2015.2.1.88

AUTHOR'S AFFILIATION

Department of Botany, R.P.M. College (University of Calcutta), Uttarpara, Hooghly, 712258, West Bengal, India

CORRESPONDENCE

$\triangle$ Dr. Dibyendu Talukdar, E-mail:dibyendutalukdar9@gmail.com types of flora and fauna (Biswas et al., 2014). The Nadia district is an important part of this basin, dotted with numerous wetlands, forest covers and agricultural lands (Talukdar and Talukdar, 2012). Kalyani (between $22^{\circ} 945^{\prime}-22^{\circ} 995^{\prime} \mathrm{N}$ latitude and $88^{\circ} 41^{\prime}-88^{\circ} 47^{\prime} \mathrm{E}$ longitude) is situated at the southern part of the district Nadia. Since its establishment several changes have taken place in the town. It is $50 \mathrm{~km}$ away from the capital of West Bengal, Kolkata, with mean height 7.8 msl. The soil is mainly Ganga riverine, alluvial, and arsenic contamination has recently been reported in soil, water and crops grown in this region (Talukdar, 2013b-d, 2014; Talukdar and Talukdar, 2013a, 2014). Climatically, Kalyani represents typical tropical monsoon and thus, has magnificent reserve of plant resources (Roy and Mukherjee, 2011).

However, due to excessive deforestation, human settlements, agriculture, and industrial activities the fate of local biodiversity and the future of huge human population depending on plant resource are now in danger. Despite rich in floral diversity, limited information is available regarding status and conservation of flora in this region. No comprehensive zone wise study for floral diversity has been carried out in Kayani. Considering all the above perspectives, the present field study was undertaken around Kalyani township area. Main objectives of the study were 1) inventorizing plant community, 2) to perform ecological analysis, and 3) to identify plants used in various purposes, especially for herbal medicine in the study area.

\section{Materials and Methods}

\section{Study area}

The present study was conducted in and around Kalyani University Campus area, which is located outskirts of the main township of Kalyani, Nadia, West Bengal, India. 


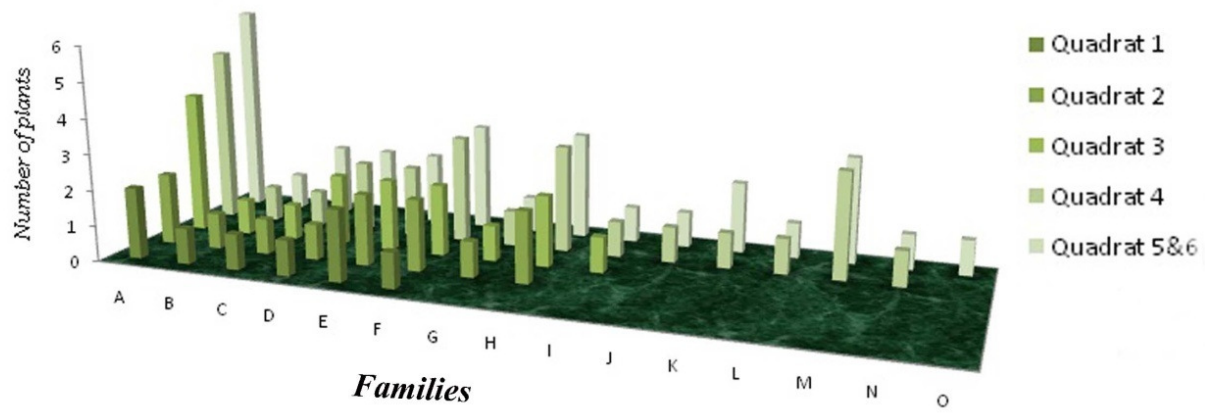

Fig 1. Comparison of families with different number of plant species found in each of 6 quadrats; In the quadrat 5 and 6 Asteraceae (A) contained highest taxa,followed by (B) Oxalidaceae (1), (C) Malvaceae (2), (D) Lamiaceae (2), (E) Poaceae (20, (F) Acanthaceae (3), (G) Convolvulaceae (1), (H) Amaranthaceae (3), (I) Ulmaceae (1), (J) Rubiaceae (1), (K) Fabaceae (2), (L) Chenopodiaceae (1), (M) Solanaceae (3), (N) Asclepiadaceae (1) and (O) Scrophulariaceae (1).

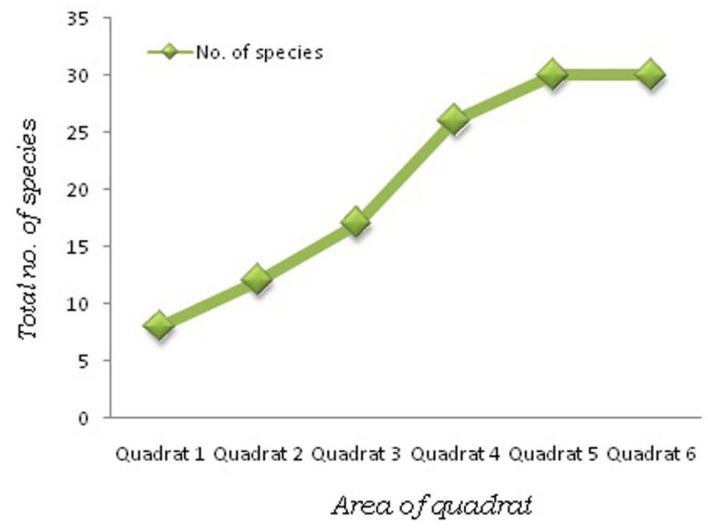

Fig. 2. Comparison of area of quadrats with total number of species. Quadrat no. 1 contains lowest number of species (8), Quadrat no. 2 (12), Quadrat no. 3 (17), Quadrat no. 4 with (26) and finally Quadrat no. 5 and 6 contain (30) species each and thus forming a plateau.

The study area was along the roadside coming straight from Kalyani Ghoshpara railway station to the Kalyani University campus in West Bengal, India.

\section{Field study}

Field work was carried out during January, 2014 to document vegetation and their uses by local communities. In study site 6 quadrats were randomly laid down for sampling of herbaceous species. This is done by sampling the vegetation with a nested quadrat method. Nested quadrats are series of quadrats laid over the others with gradually increasing size. In the present study, minimal and maximal sizes of quadrat were $30 \mathrm{~cm}^{2}$ and $180 \mathrm{~cm}^{2}$, respectively.

Density, frequency and abundance of plant species were determined on the basis of individual species observed in the quadrats lay. Diameter at breast height (at $1.35 \mathrm{~m}$ from the ground) of all the trees with $>30 \mathrm{~cm}$ circumference in each quadrat was measured and

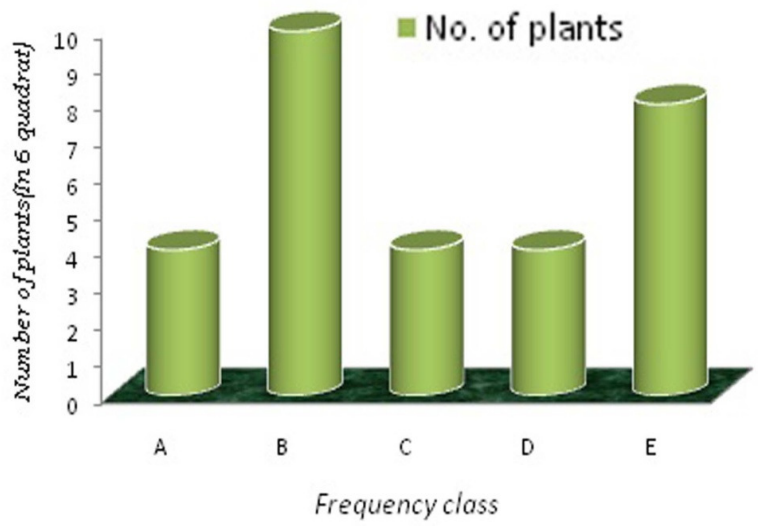

Fig. 3. Distribution of plants species in the study area under 5 frequency classes; A: 0-33.34\%, B: $34.34 \%-50 \%$, C: 51\%-66.67\%, D: 67.67\%-83.34\% and E: $84.34 \%-100 \%$, based on frequency percentage at Table 1.

recorded for each tree species. The plant species were identified using regional flora, IPNI (International Plant Names Index; www.IPNI.org), and herbarium collection in the Central National Herbarium, Sibpur, Howrah. Voucher specimen was deposited at departmental herbarium. Additionally, collected preserved/dried specimens have been digitalized as virtual herbarium (RPMC-H) in the 'Digital Phyto Informatics Center' of the Department of Botany, R.P.M. College (www.rpmcdigitalphytoinformatics.com), Uttarpara, Hooghly, West Bengal, India.

\section{Ecological parameters}

Baseline data of total plant number, frequency (\%), density and abundance were calculated following Talukdar and Talukdar (2012). The plant specimens are enlisted by using a series of square quadrats as mentioned above. 
Table 1. Number, frequency (F), density (D) and abundance $(A B)$ of plants in square quadrat methods (minimum: $30 \mathrm{sq} \mathrm{cm}$ and maximum: $180 \mathrm{sq} \mathrm{cm}$ ), data pooled from selected study site and 6 quadrats (Q1-6)

\begin{tabular}{|c|c|c|c|c|c|c|c|c|c|c|c|c|c|}
\hline \multirow[t]{2}{*}{$\begin{array}{l}\text { Sl. } \\
\text { no }\end{array}$} & \multirow[t]{2}{*}{$\begin{array}{l}\text { Botanical names, } \\
\text { habit and family }\end{array}$} & \multicolumn{6}{|c|}{$\begin{array}{l}\text { Number of individuals of the } \\
\text { species in various quadrats }\end{array}$} & \multirow[t]{2}{*}{$\begin{array}{c}\text { Total } \\
\text { (a) }\end{array}$} & \multirow{2}{*}{$\begin{array}{l}\text { Total } \\
\text { points of } \\
\text { occurrence } \\
\text { (b) }\end{array}$} & \multirow[t]{2}{*}{$\begin{array}{c}\text { Density } \\
D=a / 6\end{array}$} & \multirow{2}{*}{$\begin{array}{c}\begin{array}{c}\text { Frequency } \\
(\%) \\
\mathrm{F}=(\mathrm{b} / 6) \times 100\end{array}\end{array}$} & \multirow[t]{2}{*}{$\mathrm{AB}=\mathrm{a} / \mathrm{b}$} & \multirow[t]{2}{*}{$\begin{array}{l}\text { Frequency } \\
\text { class }\end{array}$} \\
\hline & & Q1 & Q2 & Q3 & Q4 & Q5 & Q6 & & & & & & \\
\hline 1. & $\begin{array}{l}\text { Achyranthes aspera L., M, } \\
\text { Herb, Amaranthaceae }\end{array}$ & & 1 & 5 & 8 & 10 & 13 & 37 & 5 & 6.1 & 83.3 & 7.4 & $\mathrm{D}$ \\
\hline 2. & $\begin{array}{l}\text { Amaranthus spinosus L., } \\
\text { V, Herb, Amaranthaceae }\end{array}$ & & & & 1 & 2 & 4 & 7 & 3 & 3.6 & 50 & 7.3 & B \\
\hline 3. & $\begin{array}{l}\text { Alternanthera sessilis(L.) } \\
\text { R.Br.ex DC, M, Herb, } \\
\text { Amaranthaceae }\end{array}$ & & 2 & 4 & 5 & 8 & 12 & 31 & 5 & 5.1 & 83.3 & 6.2 & $\mathrm{D}$ \\
\hline 4. & $\begin{array}{l}\text { Ageratum conyzoides L., } \\
\text { Herb, Asteraceae }\end{array}$ & 3 & 7 & 15 & 18 & 24 & 30 & 97 & 6 & 16.1 & 100 & 16.1 & $\mathrm{E}$ \\
\hline 5. & $\begin{array}{l}\text { Mikania micrantha } \\
\text { Kunth., Climber, } \\
\text { Asteraceae }\end{array}$ & 1 & 4 & 8 & 8 & 12 & 16 & 49 & 6 & 8.1 & 100 & 8.1 & $\mathrm{E}$ \\
\hline 6. & $\begin{array}{l}\text { Cynodon dactylon (L.) } \\
\text { Pers., M, Herb, Poaceae }\end{array}$ & 40 & 100 & 200 & 280 & 370 & 480 & 1470 & 6 & 245 & 100 & 245 & $E$ \\
\hline 7. & $\begin{array}{l}\text { Oxalis corniculata (DC.) } \\
\text { Raeusch, M, Herb, } \\
\text { Oxalidaceae }\end{array}$ & 6 & 10 & 18 & 25 & 32 & 40 & 131 & 6 & 21.8 & 100 & 21.8 & $\mathrm{E}$ \\
\hline 8. & $\begin{array}{l}\text { Sida cordifolia (Burm. f.) } \\
\text { Borssum, Herb, } \\
\text { Malvaceae }\end{array}$ & 1 & 1 & 2 & 4 & 10 & 15 & 33 & 6 & 5.5 & 100 & 5.5 & $\mathrm{E}$ \\
\hline 9. & $\begin{array}{l}\text { Ocimum basilicum L., M, } \\
\text { Shrub, Lamiaceae }\end{array}$ & 1 & 2 & 4 & 5 & 7 & 84 & 103 & 6 & 17.1 & 100 & 17.1 & $\mathrm{E}$ \\
\hline 10. & $\begin{array}{l}\text { Hemigraphis hirta L., } \\
\text { Herb, Acanthaceae }\end{array}$ & 1 & 4 & 44 & 50 & 57 & 62 & 218 & 6 & 36.3 & 100 & 36.3 & $\mathrm{E}$ \\
\hline 11. & $\begin{array}{l}\text { Digitaria sp., Herb, } \\
\text { Poaceae }\end{array}$ & 5 & 12 & 15 & 20 & 28 & 65 & 145 & 6 & 24.1 & 100 & 24.1 & $\mathrm{E}$ \\
\hline 12. & $\begin{array}{l}\text { Evolvulus nummularius } \\
\text { (L.), L, Herb, } \\
\text { Convolvulaceae }\end{array}$ & & 4 & 5 & 7 & 7 & 10 & 33 & 5 & 5.5 & 83.3 & 6.6 & $\mathrm{D}$ \\
\hline 13. & $\begin{array}{l}\text { Rungia pectinata Nees., } \\
\text { Herb, Acanthaceae }\end{array}$ & & 20 & 25 & 32 & 37 & 45 & 159 & 5 & 26.6 & 83.3 & 31.8 & $\mathrm{D}$ \\
\hline 14. & $\begin{array}{l}\text { Trema orientalis Bl., F, } \\
\text { Tree, Ulmaceae }\end{array}$ & & & 2 & 3 & 3 & 5 & 13 & 4 & 2.1 & 66.6 & 3.2 & $\mathrm{C}$ \\
\hline 15. & $\begin{array}{l}\text { Synedrella nodiflora } \\
\text { Gaertn., Herb, Asteraceae }\end{array}$ & & & 3 & 6 & 8 & 10 & 27 & 4 & 4.5 & 66.6 & 6.7 & $\mathrm{C}$ \\
\hline 16. & $\begin{array}{l}\text { Clerodendrum viscosum } \\
\text { Vent, Shrub, Lamiaceae }\end{array}$ & & & 1 & 1 & 1 & 2 & 5 & 4 & 0.8 & 66.6 & 1.2 & C \\
\hline 18. & $\begin{array}{l}\text { Oldenlandia corymbosa } \\
\text { L., Herb, Rubiaceae }\end{array}$ & & & & 1 & 3 & 5 & 9 & 3 & 1.5 & 50 & 3 & B \\
\hline 19. & $\begin{array}{l}\text { Tamarindus indica L., M, } \\
\text { Tree, Fabaceae }\end{array}$ & & & & 1 & 1 & 2 & 4 & 3 & 0.6 & 50 & 1.3 & B \\
\hline 20. & $\begin{array}{l}\text { Chenopodium album L., } \\
\text { Herb, V Chenopodiaceae }\end{array}$ & & & & 1 & 1 & 1 & 3 & 3 & 0.5 & 50 & 1 & B \\
\hline 21. & $\begin{array}{l}\text { Cestrum diurnum L., } \\
\text { Shrub, Solanaceae }\end{array}$ & & & & 1 & 2 & 4 & 7 & 3 & 1.1 & 50 & 2.3 & B \\
\hline 22. & $\begin{array}{l}\text { Calotropis procera } \\
\text { (Aiton), W.T.Aiton, M, } \\
\text { Shrub, Asclepiadaceae }\end{array}$ & & & & 1 & 1 & 1 & 3 & 3 & 0.5 & 50 & 1 & B \\
\hline 23. & $\begin{array}{l}\text { Physalis minima L., Herb, } \\
\text { Solanaceae }\end{array}$ & & & & 1 & 2 & 6 & 9 & 3 & 1.5 & 50 & 3 & B \\
\hline 24. & $\begin{array}{l}\text { Vernonia cinerea L., Herb, } \\
\text { Asteraceae }\end{array}$ & & & & 1 & 3 & 3 & 7 & 3 & 1.1 & 50 & 2.3 & B \\
\hline 25. & $\begin{array}{l}\text { Peristrophe bicalyculata } \\
\text { Nees, Herb, Acanthaceae }\end{array}$ & & & & 1 & 2 & 6 & 9 & 3 & 1.5 & 50 & 3 & B \\
\hline 26. & $\begin{array}{l}\text { Solanum xanthocarpum } \\
\text { Schrad \& Wendl, Herb, } \\
\text { Solanaceae }\end{array}$ & & & & 1 & 1 & 1 & 3 & 3 & 0.5 & 50 & 1 & B \\
\hline 27. & $\begin{array}{l}\text { Cassia sophera L., M, } \\
\text { Herb, Fabaceae }\end{array}$ & & & & & 1 & 2 & 3 & 2 & 0.5 & 33.3 & 1.5 & A \\
\hline 28. & $\begin{array}{l}\text { Gnaphalium } \\
\text { pensylvanium Herb, } \\
\text { Asteraceae }\end{array}$ & & & & & 1 & 3 & 4 & 2 & 0.6 & 33.3 & 2 & $\mathrm{~A}$ \\
\hline 29. & $\begin{array}{l}\text { Hibiscus vitifolius L., } \\
\text { Herb, Malvaceae }\end{array}$ & & & & & 1 & 1 & 2 & 2 & 0.3 & 33.3 & 1 & $\mathrm{~A}$ \\
\hline 30. & $\begin{array}{l}\text { Lindenbergia indica L., } \\
\text { Herb, Scrophulariaceae }\end{array}$ & & & & & 1 & 4 & 5 & 2 & 0.8 & 33.3 & 2.5 & $\mathrm{~A}$ \\
\hline
\end{tabular}

\section{Results and Discussion}

Plants are the vital part of the world's biological diversity and an essential resource for human well-being. Besides the crop plants that provide our basic food, thousands of wild plants have great economic and cultural importance for vast numbers of 
people throughout the world. The IUCN and its Species Survival Commission in accordance with various rules and recommendations of Ramsar Convention and convention on Biological diversity (1992) adopted the global strategy for plant conservation, including functional ecosystem diversity in wetlands and medicinal plants conservation (Hamilton, 2004; Leaman, 2006; Mishra and Sinha, 2012).

In the present study as many as 30 plant species (angiosperms) distributed in 15 families have been identified. Among these, 28 species were dicots and only 2 species were monocots. Out of the 15 families, dicot plants belonged to 14 families and monocots were represented by only 1 family. Family Asteraceae contained highest number of plant species, represented by 6 taxa, followed by the family Acanthaceae, Amaranthaceae and Solanaceae with 3 taxa each. Family Malvaceae, Lamiaceae and Fabaceae in dicot and family Poaceae in monocot possessed 2 taxa each and were closely followed by Oxalidaceae, Convolvulaceae, Ulmaceae, Rubiaceae, Chenopodiaceae, Asclepiadaceae and Scrophulariaceae with only 1 taxon each in the study area (Fig. 1). The predominance of Asteraceae indicates the high impact of neotropical flora in the study area.

Maximum numbers (23) of plants were herbaceous, followed by shrubs (04), trees (02) and climbers (01) documented in the present study (Table 1).

Among the baseline diversity parameters, plant frequency (\%), density (D), and abundance (AB) varied greatly in the study area. Plant frequency ranged between $33.3 \%$ and $100 \%$ with maximum frequency was recorded for Ageratum conyzoides L., Mikania micrantha Kunth, Cynodon dactylon (L.)Pers. Sida cordifolia L. Ocimum basilicum L., Hemigraphis hirta T. Anderson and Digitaria sp. and minimum for Cassia sophera L., Gnaphalium pensylvanicum Willd., Hisbiscus vitifolius L. and Lindenbergia indica Kuntze (Fig. 2). More than $80 \%$ frequency was estimated for the 12 taxa, namely Ageratum conyzoides L., Mikania micrantha Kunth, Cynodon dactylon (L.) Pers., Oxalis corniculata L., Sida cordifolia L., Ocimum basilicum L., Hemigraphis hirta T. Anderson, Digitaria sp., Achyranthes aspera L., Evolvulus nummularius L., Alternanthera sessilis (L.) DC. and Rungia pectinata Nees. (Fig. 2). Among these, Ageratum conyzoides and Mikania micrantha, both belonging to the family Asteraceae are enlisted within 100 worst invasive plant species (Lowe et al., 2000) and have found to have allelopathic effect on neighbouring crop plants (Talukdar, 2013e). Biological invasions by alien species are widely recognized second worst threat to native biodiversity after habitat destructions and impose high costs to agriculture, forestry, and aquatic ecosystems (Feng and Zhu, 2010; Talukdar, 2013f). The screening of these two obnoxious weeds in the present study thus assumes significance in this regard.

The density which denoted total number of individuals per quadrat crossed 10 value in 7 species with highest value of 245 recorded in grass Cynodon dactylon, which was followed by Hemigraphis hirta (36.3), Rungia pectinata (26.5), Digitaria sp. (24.1), Oxalis sp. (21.8), Ocimum basilicum (17.1) and Ageratum conyzoides (16.1). Rest of the species exhibited values <10. Mikania micrantha (8.1, Asteraceae), Achyranthus aspera (6.1, Amaranthaceae), and Sida cordifolia (Malvaceae) as well as Evolvulus sp. (Convolvulaceae) denoted values of 5.5 each and Alternanthera sessilis (Amaranthaceae) showed 5.1 (Table 1). Lowest density was estimated for Malvaceous shrub Hibiscus vitifolius (0.3), followed by Calotropis procera, Chenopodium album, Solanum xanthocarpum and Cassia sophera with 0.5 each.

Highest abundance value (245) was observed for Cynodon dactylon, followed by Hemigraphis hirta (36.3), Rungia pectinata (31.8), Digitaria sp. (24.1), Oxalis sp. (21.8), Ocimum basilicum (17.1) and Ageratum conyzoides (16.1). Low density but high abundance was observed for Xanthium strumarium L., Oldenlandia corymbosa L., Amaranthus spinosus L., Peristrophe bicalyculata Nees, Cassia sophera, Gnaphalium pensylvanicum and Lindenbergia indica (Table 1).

Status for 6 taxa i.e, Cynodon dactylon, Hemigraphis hirta, Digitaria sp., Oxalis sp., Ocimum basilicum and Ageratum conyzoides, exhibiting very high frequency, density as well as abundance in the study areas has been documented. Among the 6 quadrats laid, Cynodon dactylon, Mikania micrantha, Ageratum conyzoides, Oxalis sp., Sida cordifolia, Ocimum basilicum, Hemigraphis hirta and Digitaria sp. were recorded in maximum (6) number of quadrats. Among these, Ageratum, Mikania, Sida and Ocimum exhibited tremendous capacity to grow along roadside as well as deep inside the study areas. Quadrat studies revealed high frequency and abundance of some other taxa like Rungia pectinata, Achyranthus aspera, Evolvulus sp. and Alternanthera sessilis. Among these, Rungia pectinata showed highest density (26.5) and abundance (31.8) followed by the rest 3 species in the study area (Fig. 3; Table 1).

\section{Resource utilization}

Out of 30 taxa, eight plants were used as medicinal purposes such as cough and cold, diarrhea, insomnia, as febrifuge, diuretic etc., while one plant Trema orientalis Blume was used as cheap fuel wood. Tender leaves of 
Amaranthus spinosus L. and Chenopodium album L. have been used as vegetables (Talukdar and Talukdar, 2012). Talukdar and Talukdar (2013b) studied ethnomedicinal uses of different weed taxa in sub-Himalayan as well as Gangetic West Bengal. The importance of traditional knowledge in conservation of local biodiversity resources have widely been recognized (Antons, 2010).

\section{Conclusion}

The present investigation for the first time revealed rich floral diversity and utilization of local flora for medicine and other economic purposes. The Kalyani University campus region where the present study was carried out is gradually witnessing deforestation due to pressure from local developmental purposes and other industrial pollutions. Present inventory, therefore, may give vital clues in conservation of floral diversity in and around Kalyani University area.

\section{Competing interests}

Authors declare that they do not have any competing interests.

\section{Acknowledgements}

Authors are grateful to local people residing in the study area for the help they extended during investigation. Special thanks are also due to Dr. Binod Kumar Pathak, HOD, Botany for extending administrative support to the present inventory.

\section{References}

Antons, C. 2010. The role of traditional knowledge and access to genetic resources in biodiversity conservation in Southeast Asia. Biodiversity and Conservation 19: 1189-1204. doi:10.1007/s10531-010-9816-y

Biswas, S., M. Maity, S. Srimany, S. Chatterjee, T. Karmakar, R. Datta, J. Patra, M. Koley and D. Talukdar. 2014. Compositions, distributions and status of economic plants among invasive floras of Uttarpara, West Bengal, India. International Journal of Pharmacognosy 1(12): 800-809.

Feng, J. and Y. Zhu. 2010. Alien invasive plants in China: risk assessment and spatial patterns. Biodiversity and Conservation 19: 3489-3497. doi:10.1007/s10531-010-9909-7

Hamilton, A. C. 2004. Medicinal Plants, conservation and livelihoods. Biodiversity and Conservation 13:1477-1517. doi:10.1023/B:BIOC.0000021333.23413.42

Leaman, D.J. (2006). Chaoir's note. Medicinal Plant Conservation, 12, 2.

Lowe, S., S. Browne, S.M. Boudjela and S. M. De poorter. 2000. 100 of the world's worst invasive alien species. A selection from the 'Global Invasive Species Database' published by The Invasive Species Specialist Group (ISSG) a specialist group of the Species Survival Commission (SSC) of the World Conservation Union IUCN, P.12.
Mishra, P.K., and A. K. Sinha. 2012. Rice: Diversity in Bankura district of West Bengal (India). Bioscience Discovery 3: 284-287.

Roy, D. and S. K. Mukherjee. 2011. Diversity of trees in Kalyani township in West Bengal. Journal of Economic and Taxonomic Botany 35: 687-695.

Talukdar, D. 2013a. Species richness and floral diversity around 'Teesta Barrage Project' in Jalpaiguri district of West Bengal, India with emphasis on invasive plants and indigenous uses. Biology and Medicine 5: 01-14.

Talukdar, D. 2013b. Plant growth and leaf antioxidant metabolism of four elite grass pea (Lathyrus sativus) genotypes, differing in arsenic tolerance. Agricultural Research 2(4): doi:10.1007/s40003-013-0085-3

Talukdar, D. 2013c. Arsenic-induced oxidative stress in the common bean legume, Phaseolus vulgaris L. seedlings and its amelioration by exogenous nitric oxide. Physiology and Molecular Biology of Plants 19(1): 69-79. doi:10.1007/s12298-012-0140-8.

Talukdar, D. 2013d. Bioaccumulation and transport of arsenic in different genotypes of lentil (Lens culinaris Medik.). International Journal of Pharma and Bio Sciences 4(1): (B) $694-701$.

Talukdar, D. 2013e. Selenium priming selectively ameliorates weed- induced phytotoxicity by modulating antioxidant defense components in lentil (Lens culinaris Medik.) and grass pea (Lathyrus sativus L.). Annual Review \& Research in Biology 3(3): 195-212.

Talukdar, D. 2013f. Allelopathic effects of Lantana camara L. on Lathyrus sativus L.: Oxidative imbalance and cytogenetic consequences. Allelopathy Journal 31(1): 71-90.

Talukdar, D. 2014. A common bean (Phaseolus vulgaris) mutant with constitutively low cysteine desulfhydrase activity exhibits growth inhibition but uniquely shows tolerance to arsenate stress. Environmental and Experimental Biology 12: 73-81.

Talukdar, D. and T. Talukdar. 2012. Floral diversity and its indigenous use in old basin (Khari) of river Atreyee at Balurghat block of Dakshin Dinajpur district, West Bengal. NeBIO 3(2): 26-32.

Talukdar, D. and T. Talukdar. 2013a. Superoxide-dismutase deficient mutants in common beans (Phaseolus vulgaris L.): Genetic control, differential expressions of isozymes, and sensitivity to arsenic. BioMed Research International, Volume 2013, Article ID 782450, 11 pages, doi:10.1155/2013/782450.

Talukdar, T. and D. Talukdar. 2013b. Ethno-medicinal uses of plants by tribal communities in Hili block of Dakshin Dinajpur district, West Bengal. Indian Journal of Natural Products and Resources 4(1): 110-118.

Talukdar, D. and T. Talukdar. 2014. Coordinated response of sulfate transport, cysteine biosynthesis and glutathione-mediated antioxidant defense in lentil (Lens culinaris Medik.) genotypes exposed to arsenic. Protoplasma 251: 839-855. doi:10.1007/s00709-013-0586-8

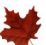

